Revista Iberoamericana, Vol. LXXVII, Núm. 235, Abril-Junio 2011, 407-424

\title{
LA POESÍA DE NANCY MOREJÓN: RENOVACIÓN DE LA EXPRESIÓN NEGRA
}

\author{
POR \\ InÉs María Martiatu TerRy \\ Unión de Escritores y Artistas de Cuba
}

Desde la aparición del libro Richard trajo su flauta y otros argumentos, aparecen en la poesía de Nancy Morejón temas recurrentes que habrán de signar su obra poética posterior y presente. Ya Nancy Morejón se había dado a conocer con Mutismos (1962), libro de juventud con el que la poeta se estrena, anuncia su presencia y se apropia de un espacio que le pertenecerá ya para siempre. En Richard trajo su flauta yotros argumentos están el amor, la familia, la raza, la ciudad natal, la música, pero también la conciencia de pertenecer a un grupo social bien definido y la exquisita feminidad de su discurso. Todo ello desemboca en una identidad asumida que la define y la contiene al mismo tiempo. También se muestra aquí el universo de la cultura popular negra a la que ya se habían acercado los exponentes del movimiento llamado Negrista o Afronegrista. Esta expresión se dio a conocer como parte de la primera vanguardia del arte y la literatura cubanos entre los años veinte y treinta del pasado siglo. Nicolás Guillén, José Zacarías Tallet, Marcelino Arozarena y Emilio Ballagas. Es bueno destacar que ese importante movimiento artístico-literario no se circunscribió a Cuba. Se desarrolló en el Caribe y aun en gran parte de la América nuestra. Esa América Latina negra, que siempre se ha creído blanca (aunque en realidad es mestiza de indio y blanco), que denigra al indio y que esconde al negro. La pujanza del movimiento negrista sobresale en la poesía, que fue quizá el género literario más exitoso y característico del mismo. Dentro de este movimiento se destacan figuras en distintas partes del continente americano además del cubano Nicolás Guillén, con sus Motivos de son; Vizcarrondo en Puerto Rico, recordado por ¿Y tu abuela dónde está?; Andrés Eloy Blanco en Venezuela con su Píntame angelitos negros; Jorge Artel con su Tambores en la noche en Colombia, entre otros.

Mónica Mansour en su libro La poesía negrista afirma que “el sentido más importante de [esta] poesía es la identificación del artista con el negro, la interpretación del negro ‘desde adentro’. De esta manera, el poeta vive las circunstancias del negro y expresa sus sentimientos”. (Jiménez) 
En ciertos casos se ha tildado de folklorista la obra de algunos representantes de este movimiento, o se ha mostrado una imagen superficial del negro. Sin embargo, un gran mérito de la obra de Nicolás Guillén fue la indudable calidad poética de su discurso. En cuanto al contenido de su poesía podemos decir que es la figura más relevante de ese movimiento. En su obra aparecen el mundo, la música, el color, la alegría, y los ritmos todos del hombre y la mujer negros. Pero también el aspecto social en lo clasista, la asunción de su origen en lo africano y de su mestizaje en lo cubano.

Esta poesía se inscribe en nuestro país en un movimiento más amplio. En esos mismos años surge en Cuba la primera vanguardia artística y literaria. Es el primer momento de reconocimiento del aporte del negro y su acervo a la cultura nacional. Este movimiento tuvo entre sus basamentos el auge de los estudios antropológicos tanto en Europa como en la propia Cuba. La base científica se debe a los estudios históricos, antropológicos, sociológicos y de historia de las artes del sabio don Fernando Ortiz. Muchos intelectuales, investigadores y artistas se agruparon alrededor de esta figura cimera, y de las instituciones y publicaciones que él fundó, inspirándose en la rica herencia africana que él ayudó a conocer. Esta es la época en que surge el afrocubanismo en las artes, pero también del auge y la internacionalización del son y de otros géneros de la música cubana en general. Las obras de todos los grandes escritores y artistas cubanos que se destacan en esta época están bajo la impronta de ese movimiento. La música sinfónica de Amadeo Roldán y Alejandro García Caturla; la pintura de Wifredo Lam; la narrativa de Alejo Carpentier y de Lydia Cabrera; el teatro lírico de Gonzalo Roig; Ernesto Lecuona y Eliseo Grenet son sólo algunos ejemplos. Una característica peculiar de esta vanguardia es que, aún cuando recibe la influencia de los movimientos estéticos del arte que se impone en los circuitos internacionales, se nutre de las raíces propias. Esta vanguardia es también una vanguardia política inmersa en los movimientos de izquierda de la época. Junto al reconocimiento del aporte del negro en la cultura, están la aspiración de la asunción de una identidad nacional y el reconocimiento de la condición de dependencia y explotación del pueblo cubano en general. Esto es una constante en todo el Caribe. La poesía de Guillén y las de otros cultivadores del Negrismo no son ajenas a los temas sociales y políticos que atañen a sus pueblos. Es una poesía comprometida. En Fundación de la imagen, Nancy Morejón escribe:

Para Nicolás Guillén, el ejercicio de la poesía ha sido un acto esencialmente vital. [...] ha servido para despertar la conciencia del obrero; en fin, para ser la voz de las más puras aspiraciones sociales, políticas y artísticas del pueblo cubano. Que no es sólo de Cuba, sino del Caribe y el resto de América Latina. (104)

Sobre todo, Guillén es el que Nancy Morejón reconoce más cercano a pesar de las diferencias en sus respectivas obras. Una amistad entrañable que el poeta mayor ejerció, además a modo de magisterio, ha sido descrita por Nancy en algunos de sus textos sobre

\footnotetext{
\begin{tabular}{l} 
Revista Iberoamericana, Vol. LXXVII, Núm. 235, Abril-Junio 2011, $407-424$ \\
\hline ISSN 0034-9631 (Impreso)
\end{tabular}
} 
Guillén. “En torno a Nicolás Guillén”, en el libro de ensayos Fundación de la imagen, es uno de los escritos que mejor ilustra esa relación (103). Aunque la autora asegure que le debe mucho a la obra de Guillén, en la suya aparecen otras connotaciones. En las obras de los poetas del afronegrismo, el tratamiento de la imagen de la mujer negra varía de unos a otros. En su poema “Madrigal”, Nicolás Guillén pone toda la gracia y sabiduría de la mujer negra en la desnudez de su cuerpo y en su desempeño sexual:

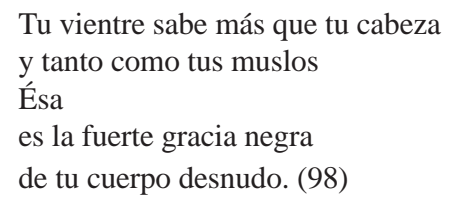

Tenemos el caso del muy celebrado poema “La rumba”, de José Zacarías Tallet, en que la descripción del cuerpo de la mujer negra se limita a las partes sexuadas y donde el juego danzario de la pareja que baila se describe como expresión de una sexualidad desenfrenada, grotesca, casi animal:

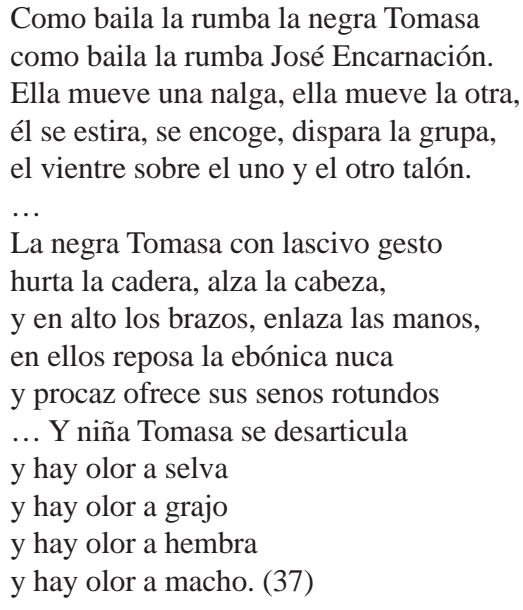

Es curioso otro ejemplo, el del poeta colombiano Jorge Artel, que, en su poema "La cumbia”, coincide con casi todas las concepciones de Tallet en cuanto al tratamiento de la mujer negra danzante. En “La cumbia”, podemos leer:

la cumbia frenética,

la diabólica cumbia,

pone a cabalgar su ritmo oscuro

Revista Iberoamericana, Vol. LXXVII, Núm. 235, Abril-Junio 2011, 407-424
ISSN 2154-4794 (Electrónico) 
sobre las caderas ágiles

de las sensuales hembras. (citado en Jiménez)

El poeta se expresa en un discurso donde el léxico se muestra siempre tendencioso. La mujer es llamada "hembra”, enfatizando su rol sexual y excluyendo todo otro rasgo de inteligencia, espiritualidad o comportamiento social. La danza misma está cargada de connotaciones que la demonizan cuando la denomina "la diabólica cumbia”:

¿Si se quiere resaltar la "sensualidad" de los afro-descendientes americanos como una característica positiva y como un modo de afirmar su identidad, por qué poner la responsabilidad sobre el cuerpo femenino? ¿Dónde queda la realidad histórico-social de la mujer de color? (Jiménez)

En su poema “Mujer Negra”, Nancy Morejón expresa su aporte en este aspecto a esa renovación de la expresión negra a que aludimos en el título de este trabajo. No destaca la belleza física, ni el impacto quizá exótico que la imagen de la mujer negra representa. La poeta la hace consciente de su historia, de sus trabajos y sus luchas, protagonista de los sufrimientos pero también hacedora esforzada de los cambios y del futuro:

Acaso no he olvidado ni mi costa perdida, ni mi lengua ancestral

$$
\text { [...] }
$$

Esta es la tierra donde padecí bocabajos y azotes.

$$
\text { [...] }
$$

... bajé de la Sierra

para acabar con capitales y usureros, con generales y burgueses.

[...]

... bajé de la Sierra

Iguales míos, aquí los veo bailar

alrededor del árbol que plantamos para el comunismo.

para acabar ...

Su pródiga madera ya resuena. (Cuerda 113-15)

Es interesante detenernos aquí y hacer énfasis en la importancia de la aparición de “Mujer Negra” en el panorama de la poesía latinoamericana y caribeña. Hasta ese momento poetas como el propio Guillén habían denotado como expresamos más arriba, una imagen sexualizada de la mujer negra. Aún más interesante es la diferencia en el tratamiento de la mujer negra y blanca como sujeto poético en las obras de algunos de estos poetas del afronegrismo. Deisy Jiménez comenta sobre la poesía de Jorge Artel:

Revista Iberoamericana, Vol. LXXVII, Núm. 235, Abril-Junio 2011, 407-424
ISSN 2154-4794 (Electrónico) 
La mujer negra o mulata es danza, movimiento, sensualidad y carne. Por otro lado, existe una mujer inspiradora de un lenguaje sentimental. En el poema "Canción para un ayer definitivo”, la presencia femenina está marcada por una atmósfera de nostalgia y amor romántico. [...] este poema no hace ninguna referencia racial sobre la mujer amada. La voz poética la ubica en un espacio celestial en el verso "como un ángel dormido". No hay una exhibición de la anatomía femenina. Por el contrario, solamente se hace mención a "su voz", "su mirada” y “su sonrisa”, que son imágenes ligadas más a la idea de un amor no carnal. Esta división de imágenes parece sugerir que la mujer "racializada" es siempre la mujer de color. Y, consecuentemente, la mujer de color es siempre la mujer sexual. (Jiménez)

Es indudable que la danza, como expresión del negro, ha sido mal entendida por algunos de los más importantes cultores del Negrismo. Y es en la descripción de la danza donde se cometen más excesos en cuanto al tratamiento de la sexualidad de la negra o la mulata.

Esta puesta en escena de la mujer de color da cuenta principalmente del deseo sexual masculino. El poeta exhibe la sexualidad femenina para demostrar su heterosexualidad. [...] El sujeto negro masculino busca afirmación sin cuestionar la sociedad patriarcal y asumiendo, probablemente, la idea de que el tema racial es un asunto entre hombres. (Jiménez)

Esta visión sexualizada en la representación de la mujer negra debe impugnarse solamente cuando se emplea de una manera reduccionista que realmente es ajena a nuestra cultura. En la mitología que acompaña a las religiones afrocubanas tenemos un ejemplo de cómo la praxis del sexo, el amor sexual, no es pecado y de ello participan los orichas. Esto se manifiesta también en lo profano. La mujer en el contexto cubano y caribeño goza del eros y de la belleza de su cuerpo con una libertad legítima que la aleja de la tradición represiva judeo-cristiana. De esta misma manera se expresa en las costumbres y en la danza (Martiatu Terry, "Chivo" 68). Tampoco se le niega este goce en la vejez, en la que se reivindica este derecho. Este ejemplo de don Fernando Ortiz nos revela ese aspecto.

[S]ólo una negra en senectud, de rostro muy surcado por los años vividos, de seno fláccidos [...] puede danzar dignamente la danza alegórica de la perpetuación de la especie, con el ritmo y el meneo de la expresión inequívoca en un rito biolátrico evocativo de la amorosa fecundidad de la Madre Naturaleza. (226)

Es por eso que Nancy Morejón se permite utilizar en el mejor sentido un símil referido a la mujer negra en "Otro nocturno", escrito para el compositor César Portillo de la Luz:

ISSN 0034-9631 (Impreso) 


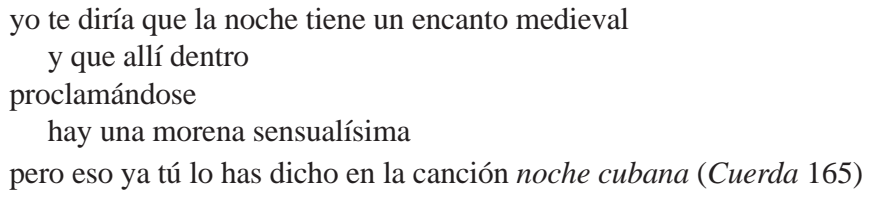

En algunos poemas del libro Richard trajo su flauta... podemos observar otros rasgos de la poesía de Nancy Morejón que la apartan del Negrismo y que alcanzan una categoría inusual. Hablamos del aspecto intimista y la presencia de lo cotidiano como en "La cena”:"

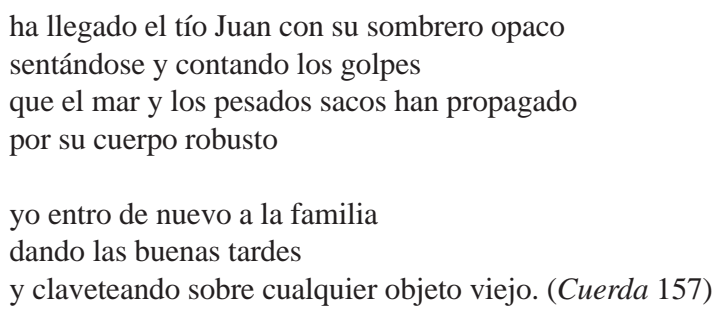

Nancy Morejón nos descubre otras facetas de un mismo mundo. Atmósferas, intenciones, una sensible y rica captación de los ambientes y sentimientos que aparecen inmersos en una atmósfera mágica, secreta y misteriosa que irrumpe introduciendo un matiz de extrañamiento. Lo anterior se ejemplica en el poema, “La cena”, cuando Morejón escribe:

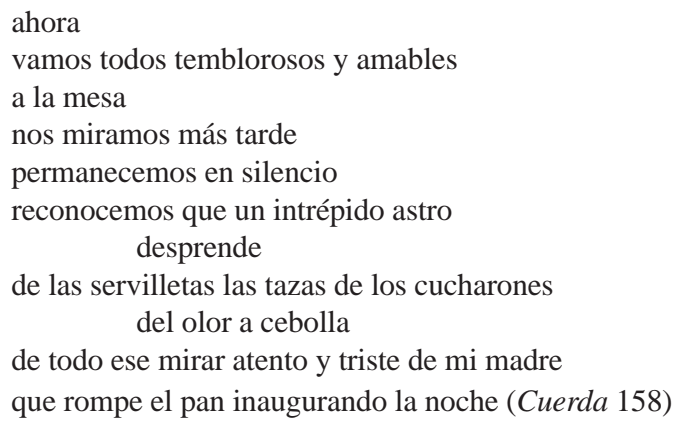

${ }_{1}$ Poema publicado originalmente en Richard trajo su flauta; la cita proviene de Cuerda veloz.

ISSN 0034-9631 (Impreso) 
En este fragmento, la poeta introduce en el ámbito de lo cotidiano el misterio de las miradas, la imagen de un intrépido astro entre los objetos familiares de la mesa, así como la capacidad prodigiosa de trasmutar lo cotidiano en la madre que "rompe el pan inaugurando la noche".

La llamada cultura popular, sus elementos más característicos, se encuentran, por supuesto, presentes en la poesía de Nancy Morejón. Ella misma con su obra ha contribuido sensiblemente a construirla y expresarla. La herencia en que se inscribe nos remite también a la poesía popular de un Gabriel de la Concepción Valdés (Plácido) (1809-1844) o de un Francisco Poveda, como bien nos refiere José Lezama Lima (“Conferencia” 123-24). Ellos fueron, junto a José María Heredia, José Jacinto Milanés y José Martí, algunas de las voces que caracterizaron el parnaso cubano del siglo xIX.

Es importante señalar que la llamada cultura popular tradicional entre nosotros se diferencia de la cultura de masas. El término "cultura popular tradicional” vino a sustituir al de "folklore" por las conocidas connotaciones colonialistas de este. Sin embargo, "cultura popular tradicional" engloba religiones, artesanía, literatura oral, música, danza, y otras manifestaciones consideradas tradicionales. Este es un tema polémico. A mi entender, tal como se usan, los términos folklore y cultura popular tradicional son equivalentes e igualmente constituyen una generalización abusiva inconcebible si se tratara de las culturas hegemónicas en las que no se reducirían de esa manera tan disímiles especialidades y saberes. Por otro lado, la oposición cultura popular tradicional-cultura universal contemporánea es en sí una forma de descalificar a la primera. En realidad en Cuba tenemos un discurso cultural hegemónico que se opone a estas manifestaciones del pueblo en que el elemento de origen africano es determinante. Ese discurso que se cree más heredero de lo europeo que de lo africano se ha visto, aún sin quererlo, influenciado por la cultura negra (Martiatu Terry, "Chivo” 193).

Si la poesía de Guillén surge de aquella primera vanguardia, la de Nancy Morejón, heredera de ella, aparece en la segunda vanguardia de los sesenta, el segundo y más importante momento de reconocimiento del aporte del negro y de las culturas africanas a la identidad nacional. En esta etapa también se debe destacar la labor de científicos sociales junto a la de músicos, artistas plásticos, coreógrafos y teatristas, que conforman un movimiento de gran creatividad.

En una lectura de Fundación de la imagen se evidencia la sólida formación histórica de la Nancy Morejón ensayista. Ella aborda temas medulares de la historia y de la cultura caribeñas con una información y comprensión notables. No nos asombra que Nancy Morejón escriba aquí sobre Nicolás Guillén, ni que dedique uno de sus más agudos ensayos a Jacques Roumain, el poeta haitiano a quien admira y con quien se siente profundamente identificada: "La vida y la obra de Jacques Roumain son el espejo de la historia trágica de Haití” (Fundación 203). En otro de estos ensayos ella celebra el talento luminoso de Stephen Alexis, el creador de El compadre general sol y otras

Revista Iberoamericana, Vol. LXXVII, Núm. 235, Abril-Junio 2011, $407-424$
ISSN 0034-9631 (Impreso) 
narraciones notables y su sacrificio consecuente luchando por la libertad de Haití. Con el análisis de la obra y la personalidad de Edward K. Brathwaite, Morejón se acerca a la sustancia antillana que nos hermana con el Caribe anglófono. Ella reconoce en la obra de estos poetas, como en la de George Lamming o Roberto Fernández Retamar, "el afán de encontrar la legítima identidad de las Antillas” (Fundación 237). Destaca con ello la correspondencia entre la comprensión histórica e identitaria de estos poetas y su toma de conciencia que los hizo asumir una responsabilidad política e histórica frente a los difíciles destinos de sus países y sus pueblos. Nancy Morejón se inscribe ella misma en esa tradición. Esta es una de las claves insoslayables de su poesía y de su compromiso social. Comparando los versos del poema "Madera de ébano", de Jacques Roumain, con los de "Mujer Negra", de Nancy Morejón, podemos apreciar cómo la asunción de lo africano deviene conciencia, esperanza de humanidad en el futuro:

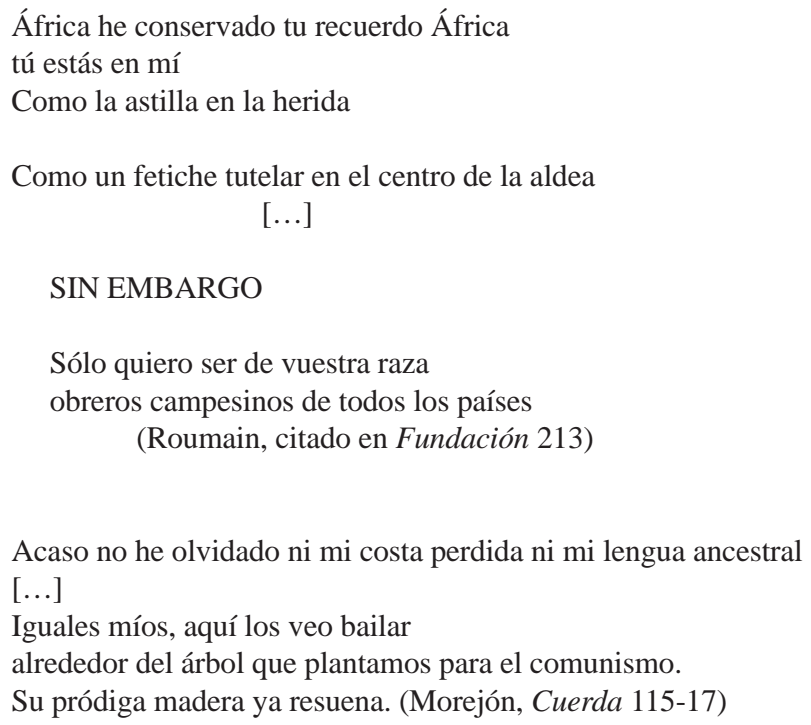

Uno de los elementos fundamentales de la expresión poética del negro es la música. En Nicolás Guillén es el son el que acompaña el descubrimiento de una nueva sensibilidad, aportando originales resonancias y un ritmo inconfundible que habrá de caracterizar la zona más conocida de la poesía de este coloso de las islas. En Nancy Morejón, más allá de la influencia guilleneana, está la música en una vertiente que ha expresado la sensibilidad del cubano en su faceta más íntima. Me refiero particularmente a la canción en sus formas urbanas.

La llamada trova tradicional surge a finales del siglo XIX y principios del xx. Es una expresión propia de la vida citadina de la época. Sus cultores pertenecían a la

Revista Iberoamericana, Vol. LXXVII, Núm. 235, Abril-Junio 2011, $407-424$
ISSN 2154-4794 (Electrónico) 
clase más humilde y desarrollaban su arte en condiciones precarias, vivían la bohemia en noches de serenatas, reuniones en cafés o en viviendas muy pobres, incluso en “solares”. Influenciada por la canción española e italiana, la trova ha llegado a ser en Cuba una de las manifestaciones más trascendentes y perdurables, presente siempre en el imaginario popular. Muchas de esas obras son breves joyas literarias y musicales. La canción trovadoresca refleja un universo lírico, intimista, expresado con la más exquisita espiritualidad. En las letras de sus canciones aparecen el amor a la mujer, a la Patria, a la naturaleza. En algunos casos los compositores musicalizaron poemas escritos de antemano, pero en su mayoría son letras salidas de su propia inspiración. Todo ello es acompañado principalmente por un estilo guitarrístico de gran riqueza armónica en su interpretación. El montaje de las voces de dúos o tríos está basado en la armonía de la música occidental. El carácter de la trova desmiente algunas apreciaciones estereotipadas y reduccionistas del carácter del negro caribeño y cubano, y de sus expresiones artísticas que en muchos casos no han sido bien comprendidas en toda su riqueza y complejidad. El hecho es que la trova se mantiene viva y ha sido asumida por todo el pueblo como una expresión propia. La mayoría de los compositores e intérpretes de la trova fueron negros y mulatos de procedencia humilde, con muy raras excepciones. Entre ellos se destacan figuras como la de Manuel Corona, el autor, entre otras, de “Longina”, canción en la que se celebra la belleza y la espiritualidad de la mujer negra, a contrapelo de la exaltación de los modelos de la belleza blanca imperante en la poesía y en la canción de la época. Otra figura ejemplar es María Teresa Vera, autora de canciones antológicas como la habanera "Veinte años”. Compositora y cantante, mujer talentosa y trasgresora que desafió las costumbres de entonces, Vera llevó una vida independiente en el ambiente bohemio de los trovadores, contexto predominantemente masculino. Ella logró ser aceptada, respetada y amada como una de las figuras paradigmáticas de la trova. Esta atmósfera sonora, este lirismo, está en la poesía de Nancy Morejón. Ella evoca incluso la participación de su abuela materna en ese mundo. En el poema "Presente Ángela Domínguez”, la describe: “tú eres un poco más ligera/ cantas con trovadores y guitarras/ en la noche clarísima,/ clara como tus ojos” (Cuerda 159).

Nancy Morejón penetra en ese mundo, refleja la nostalgia que envuelve ese repertorio de canciones entrañables para ella. Y sabemos que ese lirismo no le viene sólo de sus estudios e influencia de la poesía clásica o francesa, sino también de esta cercana referencia de raigambre popular. Uno de los poemas del libro Piedra pulida puede servir como un ejemplo de la influencia del entorno trovadoresco en Nancy Morejón. En "Expresamente a un árbol” hay un acercamiento al tema del amor sirviéndose de un símil referido a la naturaleza, recurso muy caro a los compositores de la trova tradicional. Nancy introduce también la cadencia, la repetición de ciertas frases para lograr el ritmo de la canción.

Vendré a cargar tus zumos.

Vendré, en plena tempestad, a devolverte

Revista Iberoamericana, Vol. LXXVII, Núm. 235, Abril-Junio 2011, $407-424$
ISSN 2154-4794 (Electrónico) 
los días incógnitos de ayer.

Vendré, a reposar bajo tus flores. Vendré, siempre vendré a que me veas rondar, junto a tu sombra. (Cuerda 90)

A finales de los años treinta y principios de los cuarenta del siglo xx se produce una renovación significativa en el mundo de la canción cubana. Se trata del movimiento del "filin" (feeling, sentimiento). En los años cincuenta y sesenta alcanzó su mayor popularidad con las obras de importantes compositores e intérpretes, y ha permanecido en el gusto popular y ha alcanzado una repercusión importante en el ámbito de la canción latinoamericana y caribeña. Tener filin, sentimiento, cantar con filin, se convirtió en la premisa de un grupo de jóvenes amigos que se reunían para hacer música e intercambiar canciones. Eran jóvenes de procedencia modesta, en su mayoría estudiantes o trabajadores, casi todos negros y mulatos que se hacían llamar "los muchachos del filin”. La canción de filin o el bolero de filin, como se le llama, se acompaña fundamentalmente con la guitarra, incorpora armonías novedosas tomadas del jazz e incluso recibe influencias de la música de concierto, de compositores como Claude Debussy y otros, de los cuales utiliza ciertos recursos expresivos. En sus letras muestra un universo intimista, con preferencia en los temas amorosos. Hay una evolución en el lenguaje de las letras de las canciones. Adquieren un carácter muy coloquial que refleja el ámbito urbano y habanero de aquellos años, con sus clubes nocturnos, su clara influencia recíproca entre los músicos cubanos y norteamericanos que actúan muchas veces juntos tanto en La Habana como en Estados Unidos. La improvisación, propia del jazz pero también de otras formas de la música cubana con raíz africana, le da un matiz peculiar a la interpretación. No solamente se dice "tener filin", sino "tener swing". Aparecen las llamadas "descargas" (término muy usado en el jazz latino o afrocuban jazz). Eran reuniones en que se hacía música en casas particulares o en locales más bien pequeños en los que la intimidad estaba garantizada. Algunos compositores que no eran propiamente cantantes, "decían" más que cantaban sus canciones en un estilo que acentuaba aún más el carácter coloquial de esas composiciones. La improvisación y el intercambio entre autores e intérpretes caracterizaban el ambiente de los protagonistas y seguidores del filin.

En los años sesenta, momento en que se encuentra en la adolescencia, en plena etapa de descubrimientos, Nancy Morejón se ve inmersa en ese mundo. Ella y otros poetas de su generación asistían deslumbrados a los clubes nocturnos de La Habana de entonces, donde actuaban los compositores e intérpretes de esta modalidad musical. En las calles de La Habana, la ciudad de Nancy, están sus gentes, su vida nocturna con sus grandes cabarets pero, sobre todo, con sus clubes pequeños donde reinaban los más importantes cultores del filin y establecían una comunicación inigualable con sus seguidores en un ambiente íntimo e irrepetible. Canciones, conversaciones cercanas entre los intérpretes

\footnotetext{
Revista Iberoamericana, Vol. LXXVII, Núm. 235, Abril-Junio 2011, $407-424$
ISSN 0034-9631 (Impreso)
} 
y su público, daban un carácter participativo a las noches de "descarga” en un piano bar, o en un pequeño club, que eran los lugares más apropiados para esta clase de intercambio. El pequeño lobby del hotel Saint John era el santuario de los seguidores de El King, José Antonio Méndez. En el piano bar del club Scherezada, descargaban Elena Burke, la Señora Sentimiento y el gran César Portillo de la Luz. El Gato Tuerto fue uno de estos lugares ya históricos (Valdés 311). Allí se reunían músicos y poetas. No es raro que a las canciones y las conversaciones se agregaran los poemas, iniciando una rica relación entre los poetas de los sesenta y los autores y cantantes. Muchos de estos poetas pertenecían al grupo que se nucleó alrededor de Ediciones El Puente, entre los que se encontraba Nancy Morejón. El dramaturgo y poeta Gerardo Fulleda León, que perteneció a ese grupo, se refiere a esta etapa (69-81). A mi modo de ver, es en la poesía de Nancy donde se hace más ostensible esta relación. Lo cotidiano, el ritmo de la vida de la ciudad, sus calles y parques, sus clubes nocturnos y, sobre todo, esa atmósfera única que sólo puede surgir entre canciones, conversaciones y poemas es recreada en su poesía. Lo cotidiano y lo coloquial a la manera de la canción están presentes. La notable compositora de filin, Marta Valdés, ha llegado incluso a musicalizar poemas de Nancy. Un ejemplo es la versión del poema “Cuerpo puro” (Valdés 313).

Nancy Morejón le ha dedicado algunos de sus poemas más significativos al filin y a sus compositores, quienes han estado muy cerca de ella. Ya en su libro Richard trajo su flauta y otros argumentos, ella le dedica un espacio importante a esta modalidad de la canción popular cubana. En algunos poemas no sólo se expresa con filin, a la manera de esos autores, sino que introduce la letra de las canciones en el propio texto estableciendo así una continuidad entre la poesía y la canción. "Requiem para la mano izquierda" está dedicado a Marta Valdés, en él se refiere a la canción "En la imaginación” de esta misma compositora:

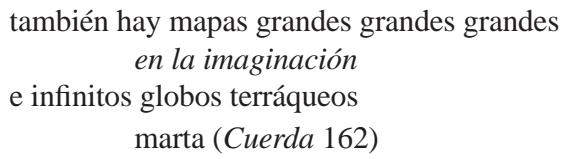

En “Adiós felicidad”, Morejón utiliza el mismo título de la canción de la autora Ela O’Fárrill.

y un día

un solo día

sólo bastará un día

pasará solitaria mugrienta

dando el perfil

querida Ela

Revista Iberoamericana, Vol. LXXVII, Núm. 235, Abril-Junio 2011, 407-424
ISSN 2154-4794 (Electrónico) 
sin descender siquiera

sin volverse (Cuerda 166)

No es casual que Nancy Morejón haya dedicado uno de sus más importantes libros de madurez a la danza. La danza es una de las expresiones más plenas y constantes en el Caribe. El vodú, la santería y otras han sido llamadas religiones bailadas. Es la danza parte de la herencia que nos dejaron nuestros aborígenes con el areíto. La danza se da en el ámbito cubano en sus más disímiles formas y funciones. En el colectivo multitudinario de la comparsa carnavalesca, que en su arrollar arrastra a todos. En los recintos religiosos en que se celebra la llegada de dioses y espíritus, en cuyos movimientos y expresiones los creyentes perciben con ansiedad el presagio. En los transportes de los espiritistas “cordoneros" que potencian su energía con las manos enlazadas, o en la transfiguración del rostro del bailarín medium cuando presta su cuerpo a la divinidad.

Con la danza el hombre concita la energía que brota de la tierra, madre de todos, ella invade su cuerpo y allí hace eclosión. En su danza, Yemayá toma la energía que brota de la tierra y la lleva al plexo solar para anunciar su presencia; Ochún la hace subir a la pelvis y luego a los hombros; Changó atrae la poderosa fuerza de los rayos hasta su sexo para que sean tributarios de su virilidad. A través de la danza, el bailarín sigue el ritmo, burla el tiempo, domina el espacio. El ritmo lo rige, pero la melodía le recorre el cuerpo. Sólo con la energía de la tierra se logra el milagro.

En la danza, en su gestualidad y movimientos, se expresan y trasmiten mensajes que pueden ser descifrados por los otros, de ahí su carácter trascendente. Esta trascendencia es llevada también a la fiesta profana, al baile popular, a la gestualidad y a la manera de andar de hombres y mujeres que se mueven por nuestras calles con esa impronta rítmica, melodiosa y a veces grave. Es lo que artistas como Alicia Alonso o Nieves Fresneda ofrecen en la peculiaridad de un arte coreográfico singular. Hay que destacar la categoría que Nancy Morejón le da al arte de Nieves Fresneda. La poeta con su fina sensibilidad reconoce el exacto valor del arte de la gran bailarina de honda raigambre popular. Su danza llega de la calle, de las comparsas, de los templos en que se adora a los orichas, a conquistar los escenarios donde había sido subestimado por no corresponder a los cánones del discurso cultural hegemónico. “Elogio de Nieves Fresneda” es uno de esos poemas raigales en que Nancy expresa su amor por las más insondables esencias de la isla, de sus dioses y sus hombres. De Nieves Fresneda la propia Nancy ha dicho que "su baile para Yemayá constituía todo un prodigio". Pero dijo más en el poema:

Sus pies marítimos,

al fin,

troncos de sal,

perpetuos pies de Nieves,

alzados como lunas para Yemayá. (Cuerda 134-35)

Revista Iberoamericana, Vol. LXXVII, Núm. 235, Abril-Junio 2011, $407-424$
ISSN 0034-9631 (Impreso) 
La Habana, la ciudad natal de Nancy Morejón, está presente en toda su obra. Aparentemente extrovertida, abierta al mar y al bullicio de sus barrios diferentes, susceptible de ser leída en su historia con sólo recorrerla desde su nacimiento en los edificios, parques y plazas de sus barrios fundacionales, La Habana Vieja. Pasando por los abigarrados barrios que fueron de Extramuros, más allá de una muralla pretendidamente protectora ya superada por el crecimiento espontáneo de la ciudad en el momento de su terminación. En uno de esos barrios de la parte de Extramuros, Los Sitios, nació y vive Nancy Morejón. Ahora este barrio pertenece a Centro Habana, municipio que lleva ese nombre por derecho propio. Aquí ha vivido siempre gente modesta, pero de disímil procedencia. El elemento negro es aquí mayoritario con sus tradiciones, santería, rumba, comparsas, Sociedad Secreta Abakuá y su historia de trabajo, luchas obreras y los afanes de una clase media. Los negros han convivido con el blanco pobre y los inmigrantes españoles, chinos, árabes y sus descendientes. Esta fusión viene de tiempo atrás, desde que la ciudad comenzó a crecer y aquí se refugiaron en viviendas modestas, más allá de las mansiones ampulosas que rodean las plazas y calles principales del recinto intramural.

La gente de La Habana sorprende al visitante no avisado con sus conversaciones en alta voz, su forma de mirar al interlocutor incluso directamente a los ojos. Viejos y jóvenes son capaces de tratar a alguien de tú al primer encuentro, de gesticular tocando atrevidamente un hombro o un brazo y hasta de entablar las más indiscretas o desconcertantes conversaciones en plena calle, en un café, en una guagua, un parque o el muro del malecón. Pero en otra faceta quiere acercarse aún más, adivinar, entrar en la intimidad sin haber sido llamado, y sorprender. Los ojos pueden revelar de pronto y sucesivamente angustia, dolor, ira, alegría, sin que sepamos por qué y comienzan a mirar más allá. Los oídos alertas presienten un rumor que no se escucha, una presencia inapresable que se percibe inquietante. Es el misterio.

El culto a los muertos está presente en las tradiciones, sobre todo de origen africano, que se conservan en Cuba. La santería con sus orichas y egguns, el palomonte con sus nkisis, los abakuás con sus íremes o los "seres” del espiritismo, tan practicado en Cuba y mezclado con las religiones traídas por los esclavos de África. Todos forman parte del misterio y nos proponen una comunicación otra entre los vivos y los muertos. Los muertos permanecen en la cotidianeidad de los vivos, ellos llenan de misterios y signos secretos los rincones de las casas. En el hogar hacen ostensible su presencia mediante sencillos ritos cotidianos. En una mirada, en el agradecimiento por el pan, por la vida o el amor. Ellos están allí, presentes, interviniendo, dándole otro matiz a la manera de expresarnos y relacionarnos. Nancy les dedica un poema,"Los muertos”:

Los muertos vienen de noche

o vienen por la tarde

a comer en las jícaras,

ISSN 0034-9631 (Impreso) 
en los atriles,

en las gargantas ajenas (Quinta 13)

Esto condiciona las relaciones entre los vivos y los muertos, pero también entre los vivos. Incluso aprendemos a reconocer las más imperceptibles señales en el ambiente, en las personas y las cosas, en los movimientos, signos y miradas. En el poema "El Café” se nos muestran algunas de las infinitas posibilidades de la comunicación entre dos seres entrañablemente unidos, madre e hija, en un momento en que un rito cotidiano, el del café, se hace sorprendentemente revelador de sutiles significados:

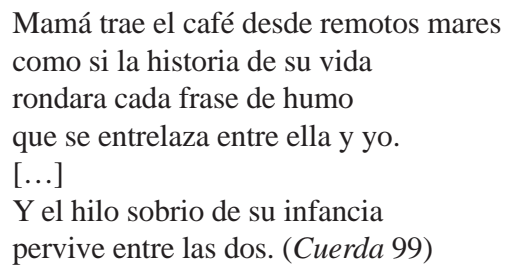

Los hechos y las cosas adquieren secretos significados más allá de lo semántico que la poeta es capaz de revelarnos a través de la poesía. Es en esa dimensión otra, nada externa, por cierto, en la que Nancy Morejón se mueve como poeta con toda confianza y maestría. Es ese el misterio develado de las palabras, el que ella convierte en imágenes. Un gran aporte de Nancy Morejón es mostrarnos la esencia de las relaciones más sutiles, de la comunicación y el deseo de los seres que anhelan expresarse. Es esa otra forma subyacente en que dialogan los vivos en su espiritualidad, su forma más sensible y secreta que han aprendido de tanto comunicarse con los muertos.

Cuando Nancy Morejón escribe "Los ojos de Eleggua”, caracteriza, reconoce, celebra al oricha:

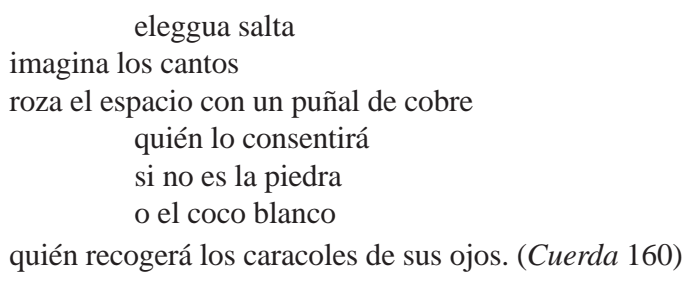

De otra manera Morejón se refiere a ese oricha tutelar del panteón yorubá en sus relaciones cotidianas con hombres y mujeres en el largo poema "Richard trajo su flauta", originalmente publicado en el libro del mismo nombre:

Revista Iberoamericana, Vol. LXXVII, Núm. 235, Abril-Junio 2011, 407-424
ISSN 2154-4794 (Electrónico) 
(es lunes y algunos de nosotros ha encendido su vela gran vela semanal para eleggua no hay nada que decir sólo tomar una botella de ron al lado de la puerta) (Cuerda 169)

No es sólo repetir el nombre o el atributo de un oricha, no es sólo evocar de pronto a un ser querido, la abuela. Aún cuando ella se refiere a su madre y a su padre vivos en poemas como "Madre” o "La cena”, establece esa cercanía signada por la intuición.

En el poema "Madre" es Nancy la que adivina, la que percibe con sólo la presencia del ser amado, todo lo que aquella trae consigo. Todo el trasfondo de dolor, a pesar de la fortaleza y valentía de esa mujer, es una historia de la que la madre no puede desprenderse o quizá no quiera:

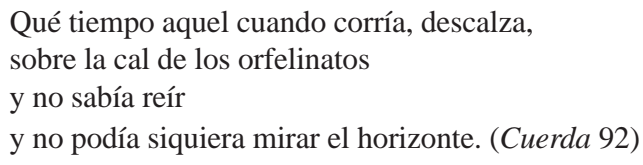

En todo ello se sustenta la fuerza con que la madre ha sido capaz de construir un mundo de amor, delicadeza y dignidad, que es el hogar en que Nancy Morejón ha crecido y crece en el amor de sus padres:

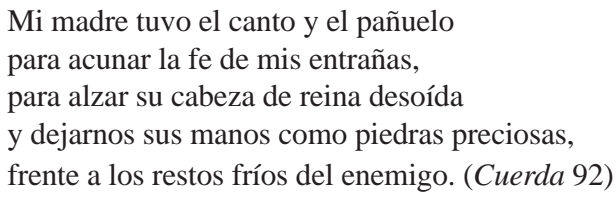

Es interesante analizar algunos de los recursos de que Nancy Morejón se vale para expresar estas sutiles relaciones señaladas más arriba. En uno de sus poemas más sugerentes, "Restos del Coral Island”, utiliza la yuxtaposición de discursos paralelos. Desde el título, "Restos del Coral Island", nos hace evocar todo el salitre y la sustancia tumultuosa de las aguas caribeñas, como lo denota su mismo nombre en inglés. Imaginamos los barcos entre las islas y la tierra firme, los barcos negreros o no, que eran los vehículos imprescindibles en aquel Caribe sin aviones: "Esa chatarra que se ve en la orilla / son los restos del Coral Island'” (Cuerda 47). Las palabras del padre anuncian la decadencia del que otrora fuera un orgulloso trasatlántico. Pero Nancy introduce aquí una digresión que expresa todo el desasosiego y lo no dicho entre los dos:

No quise preguntarle porque me dió un vuelco el corazón.

Un zumbido de mariposas también me impidió hacer preguntas.

Revista Iberoamericana, Vol. LXXVII, Núm. 235, Abril-Junio 2011, $407-424$
ISSN 0034-9631 (Impreso) 
Mi padre me miró de un modo peculiar.

¿Habíamos entrado los dos

a reconocernos en aquel himno del pasado? (Cuerda 47)

Y luego opone como contrapunto una historia de amor,

Y pensé en una historia de amor,

en una pasión desmoronada sobre dientes de perro y espuma

de mar.

Una loca pasión bien muerta,

fenecida, (Cuerda 47)

Esa historia de amor no sólo sirve como contrapunto, sino como vibración. Establece así la comunicación entre una y otra sensibilidad, entre el discurso del padre y el de la hija. Aunque están hablando de la decadencia de una nave y la dramática muerte de un amor.

En este mundo los espíritus están, permanecen e intervienen, sus voces se escuchan y sus señales pueden aparecer y percibirse. A veces nos sorprenden y enseguida sabemos cuál es el susurro, la visión que trae el mensaje, la que viene de otros tiempos y lugares. En una entrevista concebida al académico Gabriel A. Abudu, Nancy Morejón relata una experiencia singular refiriéndose a la génesis de la inspiración de su poema más célebre, "Mujer Negra":

Yo pienso que es mi poema más feliz. Cuando lo leo, me digo que es un poema simple y pienso que lo escribí de una forma irracional. Soy de la opinión de que hay una zona en el proceso creativo de un escritor, un poeta, un artista que es irracional. Hay cosas que uno vive pero de las cuales no es consciente, hay muchas cosas que vienen del subconsciente. [...] Puedo decir que fui llevada por un impulso. Súbitamente tuve como una visión de una mujer esclava frente a mí, que fue mostrándome su vida en escenas, que yo iba observando. Y entonces escribí el poema. Este poema está escrito en primera persona pero no es autobiográfico. Presumiblemente es un "yo” que es al mismo tiempo un "nosotros”, como el gran poeta norteamericano Walt Whitman sugirió. [...] Es un poema épico. ("Nancy” 39)

Nancy Morejón, con su obra, ha prestado su voz a los llamados "gente sin historia" y no quisiera dejar de referirme a ese poema sobrecogedor que es "El río de Martín Pérez”. El río de Martín Pérez pasa por una muy modesta urbanización de un suburbio de La Habana. Allí confluyen los pobres y los adoradores de los orichas quienes dejan en él las ofrendas, los despojos del sacrificio, sus dolores y su esperanza:

arrastrando en su curso

frágiles granos de maíz,

Revista Iberoamericana, Vol. LXXVII, Núm. 235, Abril-Junio 2011, 407-424
ISSN 2154-4794 (Electrónico) 
cabezas huecas de carneros,

plumas de pavo real,

ojos de gallo viudo

y brebajes del cielo. (Quinta 32)

En el poema, Nancy insiste en la pobreza fluvial de ese río, minúscula corriente, "para rescatar tus aguas pocas”, “y tanta agua pequeña, / Río de aguas ningunas”. Pero luego escribe:

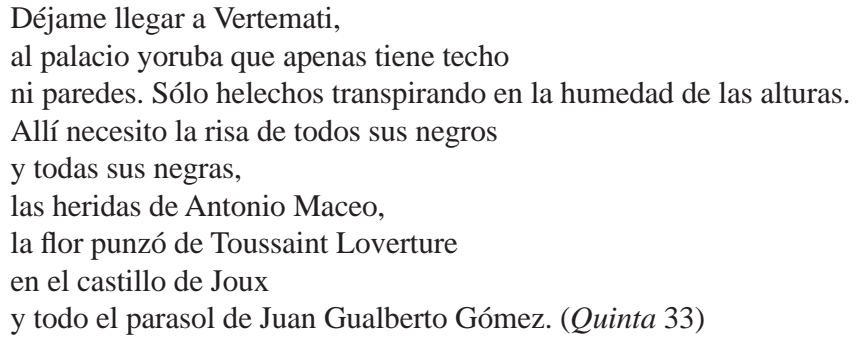

En este hermosísimo poema que nunca deja de conmoverme, Nancy Morejón, fiel a su vocación poética de retomar el hilo de la historia de esos negros y negras, los reivindica revelando el verdadero sentido épico con que se han sabido levantar contra sus penas y sus miserias. Ellos han luchado y han entrado en la historia con Maceo, Loverture, Gómez, héroes populares y ya míticos de Cuba y del Caribe.

Pero nada mejor para terminar que las palabras de la propia Nancy Morejón:

He buscado sin tregua darle voz a un coro de voces silenciadas que, a través de la historia, mucho más allá de sus orígenes, su raza o su género, renacen en mi idioma. [...] Me ha importado la Historia en letras grandes y me importó la historia de abuelas pequeñitas, adivinadoras, las que bordaron el mantel donde comían sus propios opresores. Historia de látigo, migraciones y estigmas que llegaron por el mar y al mar vuelven sin razón aparente. (Cuerda 7-8)

\section{BiBLIOGRAFÍA}

DeCosta-Willis, Myriam, ed. Singular Like a Bird: The ArtofNancy Morejón. Baltimore: Howard UP, 1999.

Fulleda León, Gerardo. "An Aesthetic of Human Provocation. An interview.” Singular Like a Bird: The Art of Nancy Morejón. Baltimore: Howard UP, 1999. 69-81.

Howe, Linda. “Nancy Morejon's Womanism.” Singular Like a Bird: The Art of Nancy Morejón. Myriam DeCosta-Willis, ed. Baltimore: Howard UP,1999. 152-168.

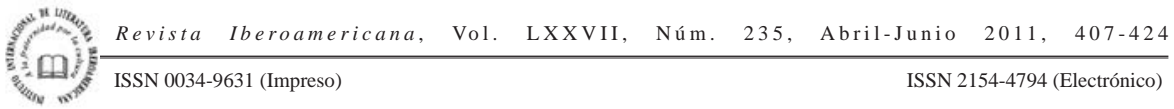


Guillén, Nicolás. Nicolás Guillén: Obra poética. Tomo I. La Habana: Letras Cubanas, 2002.

Jiménez, Deisy. “Tambores en la noche, de Jorge Artel: la mujer de color y su imaginario sexual”. La casa de Asterión. Revista Trimestral de Estudios Literarios VII/25 (2000). <http://casadeasterion.homestead.com/v7n25artel.html>. 16 feb. 2011.

Lezama Lima, José. “Conferencia sobre Gabriel de la Concepción Valdés Plácido”. Fascinación de la memoria. Textos inéditos de José Lezama Lima. La Habana: Letras Cubanas, 1993. 105-31.

Martiatu Terry, Inés María. “Chivo que rompe tambó: santería, género y raza”. Una pasión compartida: María Antonia. Inés María Martiatu Terry, sel. y pról. La Habana: Letras Cubanas, 2004. 32-74.

"Transculturación e interculturalidad: algunos aspectos teóricos". El rito como representación. La Habana: Unión, 2000. 176-94.

Morejón, Nancy. Cuerda veloz: antología poética, 1962-1992. La Habana: Letras Cubanas, 2002.

Fundación de la imagen. La Habana: Letras Cubanas, 1988.

"Nancy Morejón: An Interview". Entrevista por Gabriel A. Abudu. Singular Like a Bird: The Art of Nancy Morejón. Myriam deCosta-Willis, ed. Baltimore: Howard UP, 1999. 37-42.

La Quinta de los Molinos. La Habana: Letras Cubanas, 2000.

Ortiz, Fernando. Los bailes y el teatro de los negros en el folklore de Cuba. La Habana: Letras Cubanas, 1982.

Tallet, José Zacarías. “La rumba”. Órbita de la poesía afrocubana, 1928-1937. Ramón Guirao, ed. La Habana: Úcar García y Cía, 1938. 37.

Valdés, Marta. "And Still the Song Lingers.” Singular Like a Bird: The Art of Nancy Morejón. Myriam DeCosta-Willis, ed. Baltimore: Howard UP, 1999. 311-21.

Revista Iberoamericana, Vol. LXXVII, Núm. 235, Abril-Junio 2011, $407-424$
ISSN 2154-4794 (Electrónico) 